\section{RELATIONSHIP OFAGE WITH BODY WEIGHT IN ORPHANED LEOPARD CUBS}

\author{
B.B. Shukla ${ }^{1}$, Rakesh Kumar ${ }^{2}$, A.K.Upadhyay ${ }^{2}$, \\ S.K. Shukla ${ }^{2}$, V.P. Dixit ${ }^{2}$ and Mahesh Kumar ${ }^{2}$ \\ ${ }^{1}$ Veterinary Officer, Veterinary clinics Nohta, Damoh District, \\ Madhya Pradesh 6 \\ ${ }^{2}$ Department of Veterinary Epidemeology and Preventive Medicine, \\ College of Veterinary Sciences, G.B. Pant University of Agriculture \\ and Technology, Pantnagar, Uttaranchal 263145, India.
}

Newborn leopard cubs are totally dependent on their dam for first few weeks of life. Therefore, care of orphaned newborn cubs is an exacting task and success depends on a thorough observation and careful adoption of hygienic measures. Three orphaned leopard cubs (two females and one male) 2-3 days old were brought to the veterinary clinic in Dantewada (Chhattisgarh). Cubs weighed $340 \mathrm{~g}$ (male) and 320 and $280 \mathrm{~g}$ (2 female cubs). Their eyes were closed and appeared dehydrated. Body temperatures were recorded as normal $\left(32^{\circ} \mathrm{C}\right)$. They were 2-3 days old as their eyes were closed and opened after 7-8 days. On clinical examination, no physical injury and congenital defects were detected. These cubs were kept in a well cleaned room with proper ventilation besides, entry to the room was restricted. Umbilicus was disinfected with povidone iodine to avoid any naval infection. Lytren's warmed oral electrolyte, glucose* solution was given to them as a first meal (Benshaul, 1962)

To relieve dehydration, cubs were given electrolytes and glucose ** (C.I.V.I., 2001) using nippled bottles at hourly interval, supplemented with liver tonic (Liv-52 syrup) and vitamin supplements (ABDEC drops). Feeding frequency was eight times per day for first three weeks followed by five times a day up to eight weeks of age and then thrice a day for the rest of the period (Meier, 1986).

Cubs were fed with a mixture of cow's milk and egg yolk (Cows milk - 210ml; egg yolk - $15 \mathrm{ml}$; multivitamins - 2 drops) as per Mapletoff et al., (1974). One female cub developed gastroenteritis and revealed symptoms of anorexia, severe diarrhoea and vomitting which resulted in dehydration and died at the age of four weeks.
Male cub weighed $450 \mathrm{~g}$ and female $390 \mathrm{~g}$ at the age of one month. After one month, thoroughly boiled homogenous soup of mutton was also provided @ 100g thrice a day along with feeding with milk (Meier, 1986). Body growth of cubs was satisfactory as male attained a weight of $600 \mathrm{~g}$ and female $525 \mathrm{~g}$. At the age of two months the cubs were allowed to take soft pieces of sterilized and boneless mutton.

These cubs were reared up to six months during which periodical body profiles were taken. All the body parameters were recorded and found within normal range. There was continuous increase in the body weight of both the cubs (Table 1) during the period of their rearing.

\section{References}

Anon (2001). Current Indian Veterinary Index 2(1): 565pp.

Benshaul, D.M. (1962). Notes on hand-rearing various species of mammals. International Zoo Year Book4: 282-342.

Mapletoft, R.J., A.P. Schutt, R.L. Coubrough and R.J. Kunhe (1974). The perinatal period of dogs. Nutrition and management in the hand-rearing of puppies. Journal of South African Veterinary Association 45: 183-189.

Meier, J.E. (1986). Neonatalogy and hand rearing of carnivores, pp.842-852. In: Fowler, M.E. (ed.).Zoo and Wild Animal Medicine, $2^{\text {nd }}$ edition. W.B. Saunders Co., Philadelphia.

\section{Table 1. Age and body weight relation in leopard cubs}

\begin{tabular}{|c|c|c|}
\hline \multirow[t]{2}{*}{ Age } & \multicolumn{2}{|c|}{ Body weight of cubs (g) } \\
\hline & Female & Male \\
\hline 2 days & 340 & 320 \\
\hline 1 month & 450 & 390 \\
\hline 2 month & 600 & 525 \\
\hline 3 month & 850 & 800 \\
\hline 4 month & 1050 & 950 \\
\hline 5 month & 1500 & 1300 \\
\hline 6 month & 3250 & 2750 \\
\hline
\end{tabular}

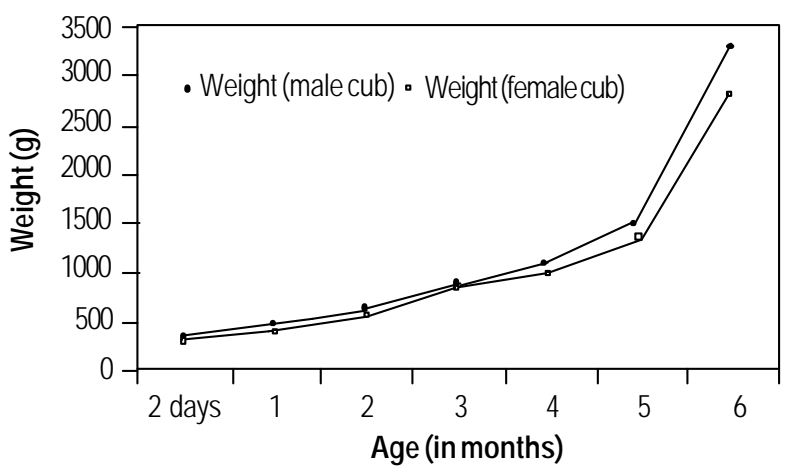

Figure 1. Age and body weight relationship in Leopard cubs

\footnotetext{
* Lytren's solution (manufactured by Mead Johnson, USA) provides 0.28 calories per $\mathrm{ml}$ instant energy, $7 \%$ carbohydrate, $30 \mathrm{mEq} / \mathrm{L}$ sodium, 25 $\mathrm{mEq} / \mathrm{L}$ potassium, $80 \mathrm{mg} / \mathrm{L}$ calcium, $84 \mathrm{mg} / \mathrm{L}$ phosphorus; ** Electral powder is marketed by FDC and contains potassium chloride (300mg), sodium chloride $(250 \mathrm{mg})$, sodium citrate $(580 \mathrm{mg})$ and dextrose $(5.4 \mathrm{~g})$ in each $7 \mathrm{~g}$ sachet.
} 